\title{
The Prevalence of Secondary School Sport Safety Policies within State Athletic Associations and Legislation
}

\author{
Samantha E. Scarneo \\ Korey Stringer Institute, University of Connecticut, samantha.scarneomiller@hsc.wvu.edu \\ William M. Adams \\ University of North Carolina Greensboro,wmadams@uncg.edu \\ Susan W. Yeargin \\ University of South Carolina, SYEARGIN@mailbox.sc.edu \\ Madeline A. Konz \\ Korey Stringer Institute, University of Connecticut, Madeline.konz@uconn.edu \\ James E. Potter \\ Korey Stringer Institute, University of Connecticut, jpotter@springfieldcollege.edu \\ See next page for additional authors
}

Follow this and additional works at: https://nsuworks.nova.edu/ijahsp

Part of the Health and Medical Administration Commons, Health Law and Policy Commons, Health Services Administration Commons, Sports Sciences Commons, and the Sports Studies Commons

\section{Recommended Citation}

Scarneo SE, Adams WM, Yeargin SW, Konz MA, Potter JE, Casa DJ. The Prevalence of Secondary School Sport Safety Policies within State Athletic Associations and Legislation. The Internet Journal of Allied Health Sciences and Practice. 2020 Jan 01;18(4), Article 17.

This Manuscript is brought to you for free and open access by the College of Health Care Sciences at NSUWorks. It has been accepted for inclusion in Internet Journal of Allied Health Sciences and Practice by an authorized editor of NSUWorks. For more information, please contact nsuworks@nova.edu. 


\title{
The Prevalence of Secondary School Sport Safety Policies within State Athletic Associations and Legislation
}

\begin{abstract}
Purpose: The location of secondary school health and safety policies impacts how they are implemented by the sports medicine team and stakeholders. Yet, a comprehensive list of each state's policy locations has not been established. The purpose of this study was to describe where secondary school health and safety policies were located at the state level within the United States. Method: Emergency related health and safety policies were designated as either being located in the state high school athletics association (SHSAA), state legislation (LEGIS), or in both SHSAA and LEGIS (BOTH). Designation was determined by two researchers who independently reviewed each individual policy. Frequencies were tabulated for the leading causes of catastrophic injury (exertional heat stroke (EHS), traumatic head injuries (THI), sudden cardiac arrest (SCA), and emergency preparedness (EP)) for the distribution of policies emanating from SHSSA, LEGIS or BOTH. Prevalence ratios (PRs) with $95 \%$ confidence intervals (Cls) were calculated between the policies categories and location. Results: Most (99.35\%) EHS and EP (83.02\%) policies were found in SHSAA. Whereas the majority (79.70\%) of SCA policies were found in LEGIS. Traumatic head injuries were most frequently observed in SHSAA, however, had the greatest distribution across all three categories (SHSAA $=45.31 \%, \mathrm{LEGIS}=25.52 \%, \mathrm{BOTH}=29.16 \%$ ). The category that most frequently found policies in BOTH was $\mathrm{THI}(\mathrm{THI}=29.16 \%$, all others $=2.25 \%$; $\mathrm{PR}=12.96 ; 95 \% \mathrm{Cl}=7.81,21.53)$. Conclusions: Emergency related health and safety policies for secondary school sports are commonly found in SHSAA. TBI and SCA are also found in LEGIS. This demonstrates great variability of policy locations.
\end{abstract}

\section{Author Bio(s)}

Samantha E. Scarneo-Miller, PhD, ATC, is the Vice President of Sport Safety for the Korey Stringer Institute at the University of Connecticut in Storrs, CT. She is also a certified athletic trainer.

William M. Adams, PhD, ATC, is an Assistant Professor in the Department of Kinesiology at the University of North Carolina Greensboro in Greensboro, NC. He is also a certified athletic trainer.

Susan W. Yeargin, PhD, ATC, is an Associate Professor of Athletic Training in the Arnold School of Public Health at the University of South Carolina in Columbia, SC. She is also a certified athletic trainer.

Madeline A. Konz, BS, EMT is a student research assistant for the Korey Stringer Institute at the University of Connecticut in Storrs, CT. She is also an emergency medical technician.

James E. Potter, BS, ATC is a student research assistant for the Korey Stringer Institute at the University of Connecticut in Storrs, CT. He is also a certified athletic trainer.

Douglas J. Casa, PhD, ATC is the Chief Executive Officer of the Korey Stringer Institute and a Professor in the Department of Kinesiology at the University of Connecticut.

\section{Authors}

Samantha E. Scarneo, William M. Adams, Susan W. Yeargin, Madeline A. Konz, James E. Potter, and Douglas J. Casa 


\title{
TIAHSP \\ The Internet Journal of Allied Health Sciences and Practice \\ Dedicated to allied health professional practice and education
}

Vol. 18 No. 4 ISSN 1540-580X

\section{The Prevalence of Secondary School Sport Safety Policies within State Athletic Associations and Legislation}

\author{
Samantha E. Scarneo ${ }^{1}$ \\ William M. Adams ${ }^{2}$ \\ Susan W. Yeargin ${ }^{3}$ \\ Madeleine A. Konz ${ }^{1}$ \\ James E. Potter ${ }^{1}$ \\ Douglas J. Casa ${ }^{1}$
}

1. University of Connecticut

2. University of North Carolina Greensboro

3. University of South Carolina

United States

\begin{abstract}
Purpose: The location of secondary school health and safety policies impacts how they are implemented by the sports medicine team and stakeholders. Yet, a comprehensive list of each state's policy locations has not been established. The purpose of this study was to describe where secondary school health and safety policies were located at the state level within the United States. Method: Emergency related health and safety policies were designated as either being located in the state high school athletics association (SHSAA), state legislation (LEGIS), or in both SHSAA and LEGIS (BOTH). Designation was determined by two researchers who independently reviewed each individual policy. Frequencies were tabulated for the leading causes of catastrophic injury (exertional heat stroke (EHS), traumatic head injuries (THI), sudden cardiac arrest (SCA), and emergency preparedness (EP)) for the distribution of policies emanating from SHSSA, LEGIS or BOTH. Prevalence ratios (PRs) with $95 \%$ confidence intervals (Cls) were calculated between the policies categories and location. Results: Most (99.35\%) EHS and EP (83.02\%) policies were found in SHSAA. Whereas the majority $(79.70 \%)$ of SCA policies were found in LEGIS. Traumatic head injuries were most frequently observed in SHSAA, however, had the greatest distribution across all three categories $(\mathrm{SHSAA}=45.31 \%$, LEGIS $=25.52 \%, \mathrm{BOTH}=29.16 \%$ ). The category that most frequently found policies in BOTH was THI (THI= $29.16 \%$, all others $=2.25 \% ; \mathrm{PR}=12.96 ; 95 \% \mathrm{Cl}=7.81,21.53)$. Conclusions: Emergency related health and safety policies for secondary school sports are commonly found in SHSAA. TBI and SCA are also found in LEGIS. This demonstrates great variability of policy locations.
\end{abstract}

Keywords: health and safety, standards, emergency care, policy, administration 


\section{INTRODUCTION}

One of the greatest threats to the health and safety of secondary school athletes is the occurrence of catastrophic injury during sport participation. The leading causes of fatal catastrophic injuries in high school sports include sudden cardiac arrest, traumatic head injuries, exertional heat stroke, and exertional sickling. ${ }^{1-3}$ With the existence of evidence-based health and safety policies specific to the prevention, management and care of these leading causes of death, many of the fatalities occurring during sport participation may be preventable if appropriately implemented. ${ }^{1,2,4}$ The utilization of health and safety policies specific to sport allow for a set standard of care for the protection of student-athletes. Although standards for health and safety may occur at various levels of the socio-ecological framework, policies housed by state entities such as legislation or high school athletics associations, have demonstrated the greatest impact of local level implementation. ${ }^{5-8}$

Health and safety policies may be housed (i.e. located) at the national and state levels providing the greatest potential benefit for athletes. ${ }^{4,5}$ However, there are no national standards that pertain to the prevention and management of all leading causes of sportrelated death and catastrophic injury in sport. ${ }^{9}$ Therefore, health and safety policies in sport are decided upon by each individual state. There are two methods in which state policy may be required: 1) governmental state legislation and 2) state high school athletics association requirements. Governmental state legislation (e.g., legislative bodies) includes laws set by the general assembly, department of education, department of public health or other department within the state's governance structure. State high school athletics associations (SHSAA), organizations that acts as the governing body for public secondary school athletics programs, may also require their member schools to follow certain policies. Previous research evaluated the implementation of evidence-based health and safety policies required by each state and reported an overall lack of implementation across the nation. ${ }^{9}$ Specifically, only $33.3 \%$ of states required policies for exertional heat stroke, $41.4 \%$ for traumatic head injuries, $60.07 \%$ for sudden cardiac arrest, and $43.02 \%$ for emergency preparedness. ${ }^{9}$ However, where the policy was located was not examined.

Athletic trainers and athletic directors report looking to the state high school athletics association or the state legislation to help determine which policies to adopt and implement at their secondary schools. ${ }^{10,11}$ Therefore, it is imperative to understand which governing body is most likely to house certain policies. Both governing bodies (legislative bodies and SHSAAs) have an impact on preventative care and safety standards within their state; however, these entities operate differently. State legislative bodies; in order to ratify a policy, a quorum in both the state senate and the state house of representatives as well as the signature of the governor of that state are needed. Simply said, state legislature can take a health and safety policy and make it law with associated legal ramifications. SHSAAs are organizations that are typically composed of administrators from high schools within each state that govern interscholastic competition, including high school sports. Policies adopted in the SHSAA are typically ratified by an executive board composed of representatives from each district within the state. SHSAA's may be in a greater degree of contact with the individuals affected by the policies they implement but may not carry the same authoritative stigma as the aforementioned particularly depending on the language of the policy.

With cooperation and open lines of communication, these governing bodies have the potential to complement each other and make impactful changes that allow for safer practices. ${ }^{12}$ No consensus exists on whether health and safety policies are more effective when implemented in one entity as opposed to the other, but information regarding the location of policies may help improve strategies for implementation in the future. Thus, the purpose of this study was to describe where secondary school health and safety policies were located at the state level.

\section{METHODS}

We utilized a cross-sectional design to evaluate the current location of health and safety policies required at the state level as evaluated in the academic year of 2016-2017. An evaluation rubric of current implementation of health and safety policies at the state level by Adams et al. was utilized in four emergency related categories: exertional heat stroke (EHS), traumatic head injuries (THI), sudden cardiac arrest (SCA), and emergency preparedness (EP). ${ }^{9}$ The rubric was developed using current evidence-based position statements, inter-association taskforce documents, and consensus statements endorsed by some of the leading medical organizations within the United States.1,2,13-16

Based on the rubric, each emergency related category had a different number of possible policies (EHS=18, THI=7, SCA=9, EP= 17). Two researchers independently reviewed the individual policies and determined if they were located in the SHSAA, state legislation (i.e., Department of Education, Department of Health, Department of Public Health, Department of Medicine, etc.) (LEGIS), or in both SHSAA and LEGIS (BOTH). The location of each health and safety policy was documented for each of the 50 states and the District of Columbia. However, only health and safety policies that were required by the state were documented. The wording of one governing entity may have been similar to the policy statement being evaluated; however, if it is was not clearly written as a requirement, it may have counted in one entity but not another. For example, if a state law did not meet the wording for the specific policy, that policy may have been considered to be present only in the SHSAA and not in BOTH. After independent 
review, the researchers met to determine if any discrepancies existed. In those cases, the location of the policy was re-evaluated until consensus was reached.

\section{Data Analysis}

The data describing the location of health and safety policies were summarized by reporting the frequency and percentages. Each of the policies evaluated for each policy section (EHS, THI, SCA, EP) were summarized by reporting the frequency of the states that required the policy as SHSAA, LEGIS, or BOTH along with the percent of the total amount of states that required that policy. For example, if policy A was required by 24 states, the SHSAA, LEGIS and BOTH percent would be calculated based on $x / 24$. For the categorical analysis, we multiplied the number of possible policies $(E H S=18, T H I=7, S C A=9, E P=17$ ) by the number of states (all 50 states plus the District of Columbia; $n=51$ ) resulting in the total amount of potential policies to be adopted if all states required all policies in the section $(E H S=918, T H I=357, S C A=459, E P=867)$. Provided the purpose of this study was to determine the location of required policies, we subtracted the number of policies not adopted for our final denominator $(E H S=311, T H I=357$, $S C A=271, E P=218)$. Categorical percent for SHSAA, LEGIS and BOTH were then calculated. Further, prevalence ratios $(P R)$ were calculated to compare the prevalence of the locations of the policies between groups. A PR not including ' 1 ' in the $95 \%$ confidence interval $(\mathrm{Cl})$ was considered statistically significant, also a PR over 1.2 was considered clinically significant. Analyses were performed in Microsoft Office Excel (Redmond, VA).

\section{RESULTS}

Overall, $60.3 \%$ (644/1067) of the health and safety policies for all four categories combined emanated from SHSAA, $32.7 \%$ (349/1067) from LEGIS, and 6.9\% (74/1067) from BOTH (Figure 1).

\section{Exertional Heat Stroke}

All EHS policies except for one were located in SHSAA. Two states (Arkansas and Maryland) have EHS policies located in legislation (Table 1).

Table 1. Exertional Heat Stroke (EHS) policy locations. Values presented as $n(\%)$ with the exception of the total column which is presented as $\mathrm{n}$, which corresponds to the number of states requiring that policy.

\begin{tabular}{|c|c|c|c|c|}
\hline POLICY & SHSAA & LEGIS & ВОТН & TOTAL \\
\hline $\begin{array}{l}\text { Days } 1-5 \text { are the first formal practices. no more than } 1 \text { practice occurs per } \\
\text { day }\end{array}$ & $\begin{array}{c}18 \\
(100) \\
\end{array}$ & $\begin{array}{c}0 \\
(0 \%)\end{array}$ & $\begin{array}{c}0 \\
(0 \%)\end{array}$ & 18 \\
\hline In days $1-5$, total practice time should not exceed 3 hours in any 1 day & $\begin{array}{c}22 \\
(100)\end{array}$ & $\begin{array}{c}0 \\
(0 \%)\end{array}$ & $\begin{array}{c}0 \\
(0 \%)\end{array}$ & 22 \\
\hline $\begin{array}{l}\text { On days 1-5, 1-hour maximum walk-through is permitted, however there } \\
\text { must be a 3-hour minimum between practice and walk-through (or vice } \\
\text { versa) }\end{array}$ & $\begin{array}{c}18 \\
(100)\end{array}$ & $\begin{array}{c}0 \\
(0 \%)\end{array}$ & $\begin{array}{c}0 \\
(0 \%)\end{array}$ & 18 \\
\hline $\begin{array}{l}\text { During days } 1-2 \text { of first formal practices, a helmet should be the only } \\
\text { protective equipment permitted (if applicable). During days } 3-5 \text {, only helmets } \\
\text { and shoulder pads should be worn. Beginning on day } 6 \text {, all protective } \\
\text { equipment may be worn and full contact may begin. } \\
\text { Football only: on days } 3-5 \text {, contact with blocking sleds and tackling dummies } \\
\text { may be initiated } \\
\text { Full-contact sports: } 100 \% \text { live contact drills should begin no earlier than day } 6\end{array}$ & $\begin{array}{c}21 \\
(100)\end{array}$ & $\begin{array}{c}0 \\
(0 \%)\end{array}$ & $\begin{array}{c}0 \\
(0 \%)\end{array}$ & 21 \\
\hline $\begin{array}{l}\text { Day 6-14, double-practice days must be followed by a single-practice day. } \\
\text { On single-practice days, } 1 \text { walk-through is permitted, separated from the } \\
\text { practice by at least } 3 \text { hours of continuous rest. When a double-practice day is } \\
\text { followed by a rest day, another double practice day is permitted after the rest } \\
\text { day. }\end{array}$ & $\begin{array}{c}17 \\
(100)\end{array}$ & $\begin{array}{c}0 \\
(0 \%)\end{array}$ & $\begin{array}{c}0 \\
(0 \%)\end{array}$ & 17 \\
\hline $\begin{array}{l}\text { On a double-practice day, neither practice day should exceed } 3 \text { hours in } \\
\text { duration, and no more than } 5 \text { total hours of practice in the day. Warm-up, } \\
\text { stretching, cool-down, walk-through, conditioning and weight-room activities } \\
\text { are included as part of the practice time. }\end{array}$ & $\begin{array}{c}27 \\
(100)\end{array}$ & $\begin{array}{c}0 \\
(0 \%)\end{array}$ & $\begin{array}{c}0 \\
(0 \%)\end{array}$ & 27 \\
\hline $\begin{array}{l}\text { On a double-practice day, the } 2 \text { practices should be separated by at least } 3 \\
\text { continuous hours in a cool environment. }\end{array}$ & $\begin{array}{c}14 \\
(100)\end{array}$ & $\begin{array}{c}0 \\
(0 \%)\end{array}$ & $\begin{array}{c}0 \\
(0 \%)\end{array}$ & 14 \\
\hline State requires all schools to have a heat modification policy & $\begin{array}{c}25 \\
(92.59) \\
\end{array}$ & $\begin{array}{c}1 \\
(3.37) \\
\end{array}$ & $\begin{array}{c}1 \\
(3.37) \\
\end{array}$ & 27 \\
\hline
\end{tabular}




\begin{tabular}{|c|c|c|c|c|}
\hline The recommended heat policy is based off of WBGT & $\begin{array}{c}5 \\
(100) \\
\end{array}$ & $\begin{array}{c}0 \\
(0 \%)\end{array}$ & $\begin{array}{c}0 \\
(0 \%)\end{array}$ & 5 \\
\hline The recommended heat policy is based off of Heat Index & $\begin{array}{c}20 \\
(100)\end{array}$ & $\begin{array}{c}0 \\
(0 \%)\end{array}$ & $\begin{array}{c}0 \\
(0 \%)\end{array}$ & 20 \\
\hline $\begin{array}{l}\text { The environmental conditions guidelines are based off of epidemiological } \\
\text { data specific to that state/region (for bigger states a more comprehensive } \\
\text { analysis may be needed) }\end{array}$ & $\begin{array}{c}8 \\
(100)\end{array}$ & $\begin{array}{c}0 \\
(0 \%)\end{array}$ & $\begin{array}{c}0 \\
(0 \%)\end{array}$ & 8 \\
\hline $\begin{array}{l}\text { The heat policy has at minimum } 4 \text { levels of modification, including the } \\
\text { modification of practice time }\end{array}$ & $\begin{array}{c}19 \\
(100)\end{array}$ & $\begin{array}{c}0 \\
(0 \%)\end{array}$ & $\begin{array}{c}0 \\
(0 \%)\end{array}$ & 19 \\
\hline Policy includes modification of equipment (if applicable to the sport) & $\begin{array}{c}20 \\
(100)\end{array}$ & $\begin{array}{c}00 \\
(0 \%)\end{array}$ & $\begin{array}{c}0 \\
(0 \%)\end{array}$ & 20 \\
\hline $\begin{array}{l}\text { Policy includes modification of work: rest ratios, including unrestricted access } \\
\text { to fluids }\end{array}$ & $\begin{array}{c}19 \\
(100)\end{array}$ & $\begin{array}{c}0 \\
(0 \%)\end{array}$ & $\begin{array}{c}0 \\
(0 \%)\end{array}$ & 19 \\
\hline Policy mentions the use of a shaded area for rest breaks & $\begin{array}{c}6 \\
(100)\end{array}$ & $\begin{array}{c}0 \\
(0 \%)\end{array}$ & $\begin{array}{c}0 \\
(0 \%)\end{array}$ & 6 \\
\hline Cold Water Immersion tubs for onsite cooling for all warm weather practices & $\begin{array}{c}8 \\
(100)\end{array}$ & $\begin{array}{c}0 \\
(0 \%)\end{array}$ & $\begin{array}{c}0 \\
(0 \%)\end{array}$ & 8 \\
\hline $\begin{array}{l}\text { If exertional heat stroke is suspected, onsite cooling using cold water } \\
\text { immersion before transport to the hospital }\end{array}$ & $\begin{array}{c}4 \\
(100)\end{array}$ & $\begin{array}{c}0 \\
(0 \%)\end{array}$ & $\begin{array}{c}0 \\
(0 \%)\end{array}$ & 4 \\
\hline $\begin{array}{l}\text { Require 4th Edition PPE forms from American Academy of Pediatrics of } \\
\text { equivalent - Heat Stroke }\end{array}$ & $\begin{array}{c}38 \\
(100)\end{array}$ & $\begin{array}{c}0 \\
(0 \%)\end{array}$ & $\begin{array}{c}0 \\
(0 \%)\end{array}$ & 38 \\
\hline
\end{tabular}

\section{Traumatic Head Injuries}

A large proportion of THI policies were found in SHSAA only (45.31\%). The distribution across SHSAA, LEGIS and BOTH was highest in the policies "High school athletes suspected of sustaining a concussion are not permitted to return to a practice, game, or activity involving exertional activity on the same day" (SHSAA $=10$ states, $19.61 \%$, LEGIS $=18$ states, 35.29\%, BOTH $=23$ states, $45.10 \%$ ) and "Athletes suspected of a concussion are not permitted to return to participation until written release from a qualified licensed healthcare professional (i.e. physician, athletic trainer, APRn, PA, etc.)" (SHSAA $=10$ states, 19.61\%, LEGIS = 18 states, $35.29 \%$, BOTH $=23$ states, $45.10 \%)($ Table 2 ).

Table 2. Traumatic Head Injury (THI) policy location. Values presented as $n(\%)$ with the exception of the total column which is presented as $\mathrm{n}$, which corresponds to the number of states requiring that policy.

\begin{tabular}{|l|c|c|c|c|}
\hline \multicolumn{1}{|c|}{ Policy } & SHSAA & LEGIS & BOTH & $\begin{array}{c}\text { TOTA } \\
\text { L }\end{array}$ \\
\hline Heads up Football training for football coaches & $\begin{array}{c}4 \\
(100)\end{array}$ & $\begin{array}{c}0 \\
(0 \%)\end{array}$ & $\begin{array}{c}0 \\
(0 \%)\end{array}$ & 4 \\
\hline Heads up Football Training for all coaches & $\begin{array}{c}0 \\
(0 \%)\end{array}$ & $\begin{array}{c}0 \\
(0 \%)\end{array}$ & $\begin{array}{c}0 \\
(0 \%)\end{array}$ & 0 \\
\hline $\begin{array}{l}\text { High school athletes suspected of sustaining a concussion are not permitted } \\
\text { to return to a practice, game, or activity involving exertional activity on the } \\
\text { same day. }\end{array}$ & $\begin{array}{c}10 \\
(19.6)\end{array}$ & $\begin{array}{c}18 \\
(35.3)\end{array}$ & $\begin{array}{c}23 \\
(45.1)\end{array}$ & 51 \\
\hline $\begin{array}{l}\text { Athletes suspected of a concussion are not permitted to return to participation } \\
\text { until written release from a qualified licensed healthcare professional (i.e. } \\
\text { physician, athletic trainer, APRn, PA, etc.) }\end{array}$ & $\begin{array}{c}10 \\
(19.6)\end{array}$ & $\begin{array}{c}18 \\
(35.3)\end{array}$ & $\begin{array}{c}23 \\
(45.1)\end{array}$ & 51 \\
\hline $\begin{array}{l}\text { No child/adolescent should return to sport/activity unless he/she has } \\
\text { managed to return to school }\end{array}$ & $\begin{array}{c}14 \\
(73.7)\end{array}$ & $\begin{array}{c}4 \\
(21.1)\end{array}$ & $\begin{array}{c}1 \\
(5.2)\end{array}$ & 19 \\
\hline $\begin{array}{l}\text { Implementation of a graduated return to participation protocol following the } \\
\text { Zurich guidelines with at least 5 steps }\end{array}$ & $\begin{array}{c}20 \\
(69.0)\end{array}$ & $\begin{array}{c}5 \\
(17.2)\end{array}$ & $\begin{array}{c}4 \\
(13.8)\end{array}$ & 29 \\
\hline $\begin{array}{l}\text { The PPE (preparticipation exam) should include concussion specific } \\
\text { questions }\end{array}$ & $\begin{array}{c}29 \\
(76.3)\end{array}$ & $\begin{array}{c}4 \\
(10.5)\end{array}$ & $\begin{array}{c}5 \\
(13.2)\end{array}$ & 38 \\
\hline
\end{tabular}

\section{Sudden Cardiac Arrest}

Sudden cardiac arrest policies are found more often in LEGIS (79.70\%) (Table 3). The policy "Require $4^{\text {th }}$ Edition PPE forms from American Academy of Pediatrics or equivalent" was required by 38 states through the SHSAA (100\%) compared to LEGIS (0\%) 
and BOTH (0\%). Whereas, the policy "AEDs are to be used under the advice and consent of a physician by individuals with proper training and certification" was required by 27 states through LEGIS (100\%) compared to SHSAA $(0 \%)$ and BOTH $(0 \%)$.

Table 3. Sudden Cardiac Arrest (SCA) policy location. Values presented as $n(\%)$ with the exception of the total column which is presented as $\mathrm{n}$, which corresponds to the number of states requiring that policy.

\begin{tabular}{|l|c|c|c|c|}
\hline \multicolumn{1}{|c|}{ POLICY } & SHSAA & LEGIS & BOTH & TOTAL \\
\hline $\begin{array}{l}\text { Require 4th Edition PPE forms from American Academy of Pediatrics or } \\
\text { equivalent - Sudden Cardiac Arrest }\end{array}$ & $\begin{array}{c}38 \\
(100)\end{array}$ & $\begin{array}{c}0 \\
(0 \%)\end{array}$ & $\begin{array}{c}0 \\
(0 \%)\end{array}$ & 38 \\
\hline $\begin{array}{l}\text { AEDs are to be used under the advice and consent of a physician by } \\
\text { individuals with proper training and certification }\end{array}$ & $\begin{array}{c}0 \\
(0 \%)\end{array}$ & $\begin{array}{c}37 \\
(100)\end{array}$ & $\begin{array}{c}0 \\
(0 \%)\end{array}$ & 37 \\
\hline AED should be stored in a safe place & $\begin{array}{c}0 \\
(0 \%)\end{array}$ & $\begin{array}{c}9 \\
(90)\end{array}$ & $\begin{array}{c}1 \\
(10)\end{array}$ & 10 \\
\hline $\begin{array}{l}\text { All athletic trainers, coaches, administrators, school nurses, and physical } \\
\text { education teachers should have access to an AED on school property }\end{array}$ & $\begin{array}{c}1 \\
(3.8)\end{array}$ & $\begin{array}{c}23 \\
(88.5)\end{array}$ & $\begin{array}{c}2 \\
(7.7)\end{array}$ & 26 \\
\hline $\begin{array}{l}\text { Institutions sponsoring athletic events/activities should have an AED on site } \\
\text { or access to one at each athletic venue for practices, games, or other athletic } \\
\text { events }\end{array}$ & $\begin{array}{c}2 \\
(13.3)\end{array}$ & $\begin{array}{c}11 \\
(73.3)\end{array}$ & $\begin{array}{c}2 \\
(13.3)\end{array}$ & 15 \\
\hline $\begin{array}{l}\text { Individuals [all personnel involved with sponsored athletic events/activities] } \\
\text { should be provided annual training and certification in cardiopulmonary } \\
\text { resuscitation (CPR) and AED use }\end{array}$ & $\begin{array}{c}3 \\
(6.3)\end{array}$ & $\begin{array}{c}41 \\
(85.4)\end{array}$ & $\begin{array}{c}4 \\
(8.3)\end{array}$ & 48 \\
\hline $\begin{array}{l}\text { Location of AED should be well marked, publicized, accessible and known } \\
\text { among trained staff }\end{array}$ & $\begin{array}{c}0 \\
(0 \%)\end{array}$ & $\begin{array}{c}15 \\
(93.8)\end{array}$ & $\begin{array}{c}1 \\
(6.2)\end{array}$ & 16 \\
\hline The AED should be used only after enacting the EMS system. & $\begin{array}{c}0 \\
(0 \%)\end{array}$ & $\begin{array}{c}34 \\
(100)\end{array}$ & $\begin{array}{c}0 \\
(0 \%)\end{array}$ & 34 \\
\hline $\begin{array}{l}\text { AEDs should be inspected frequently to ensure proper working order. This } \\
\text { includes making sure the batteries are charged, and wires and electrodes are } \\
\text { in good condition }\end{array}$ & $\begin{array}{c}0 \\
(0 \%)\end{array}$ & $\begin{array}{c}46 \\
(97.9)\end{array}$ & $\begin{array}{c}1 \\
(2.1)\end{array}$ & 47 \\
\hline
\end{tabular}

\section{Emergency Preparedness}

A majority of emergency preparedness policies were located in SHSAA (83.02\%) (Table 4). The policy component with the greatest variability across SHSAA, LEGIS and BOTH was "Every school or organization that sponsors athletics should develop an EAP specifically for managing serious and/or potentially life-threatening sport-related injuries" (SHSAA=15 states, 62.5\%, LEGIS = 8 states, $33.3 \%, \mathrm{BOTH}=1$ state, $4.1 \%)$.

Table 4. Emergency procedures (EP) policy location. Values presented as $n(\%)$ with the exception of the total column which is presented as $n$ as total states requiring policy, which corresponds to the number of states requiring that policy.

\begin{tabular}{|c|c|c|c|c|}
\hline POLICY & SHSAA & LEGIS & BOTH & TOTAL \\
\hline $\begin{array}{l}\text { Every school or organization that sponsors athletics should develop an EAP } \\
\text { specifically for managing serious and/or potentially life-threatening sport- } \\
\text { related injuries }\end{array}$ & $\begin{array}{c}15 \\
(62.5)\end{array}$ & $\begin{array}{c}8 \\
(33.3)\end{array}$ & $\begin{array}{c}1 \\
(4.1)\end{array}$ & 24 \\
\hline $\begin{array}{l}\text { The AEAP should be developed and coordinated with local EMS, school } \\
\text { public safety officials, on site medical personnel or school medical staff, and } \\
\text { school administrators }\end{array}$ & $\begin{array}{c}7 \\
(77.8)\end{array}$ & $\begin{array}{c}2 \\
(22.2)\end{array}$ & $\begin{array}{c}0 \\
(0 \%)\end{array}$ & 9 \\
\hline Every school should distribute the AEAP to all athletics staff members & $\begin{array}{c}8 \\
(80)\end{array}$ & $\begin{array}{c}1 \\
(10)\end{array}$ & $\begin{array}{c}1 \\
(10)\end{array}$ & 10 \\
\hline The AEAP should be specific to each venue (including maps, directions, etc.) & $\begin{array}{c}12 \\
(85.7)\end{array}$ & $\begin{array}{c}2 \\
(14.3)\end{array}$ & $\begin{array}{c}0 \\
(0 \%)\end{array}$ & 14 \\
\hline $\begin{array}{l}\text { On-site emergency equipment that may be needed in an emergency situation } \\
\text { should be listed }\end{array}$ & $\begin{array}{c}6 \\
(54.5)\end{array}$ & $\begin{array}{c}4 \\
(36.4)\end{array}$ & $\begin{array}{c}1 \\
(9.1)\end{array}$ & 11 \\
\hline $\begin{array}{l}\text { The AEAP should identify personnel and their responsibilities to carry out the } \\
\text { plan of action with a designated chain of command }\end{array}$ & $\begin{array}{c}7 \\
(70)\end{array}$ & $\begin{array}{c}2 \\
(20)\end{array}$ & $\begin{array}{c}1 \\
(30)\end{array}$ & 10 \\
\hline Appropriate contact information for EMS & $\begin{array}{c}6 \\
(54.5)\end{array}$ & $\begin{array}{c}4 \\
(36.4)\end{array}$ & $\begin{array}{c}1 \\
(9.1)\end{array}$ & 11 \\
\hline
\end{tabular}




\begin{tabular}{|l|c|c|c|c|}
\hline $\begin{array}{l}\text { Plan should specify documentation actions that need to be taken post } \\
\text { emergency }\end{array}$ & $\begin{array}{c}4 \\
(100)\end{array}$ & $\begin{array}{c}0 \\
(0 \%)\end{array}$ & $\begin{array}{c}0 \\
(0 \%)\end{array}$ & 4 \\
\hline AEAP should be reviewed and rehearsed annually by all parties involved & $\begin{array}{c}11 \\
(61.1)\end{array}$ & $\begin{array}{c}6 \\
(33.3)\end{array}$ & $\begin{array}{c}1 \\
(5.6)\end{array}$ & 18 \\
\hline $\begin{array}{l}\text { Healthcare professionals who will provide medical coverage during games, } \\
\text { practices, or other events should be included }\end{array}$ & $\begin{array}{c}8 \\
(80)\end{array}$ & $\begin{array}{c}2 \\
(20)\end{array}$ & $\begin{array}{c}0 \\
(0 \%)\end{array}$ & 10 \\
\hline $\begin{array}{l}\text { Coaching education required as part of coaching certification on topics } \\
\text { relating to preventing sudden death in sport }\end{array}$ & $\begin{array}{c}34 \\
(97.1)\end{array}$ & $\begin{array}{c}1 \\
(2.9)\end{array}$ & $\begin{array}{c}0 \\
(0 \%)\end{array}$ & 35 \\
\hline CPR/AED and First Aid training required for all coaches & $\begin{array}{c}29 \\
(96.7)\end{array}$ & $\begin{array}{c}0 \\
(0 \%)\end{array}$ & $\begin{array}{c}1 \\
(3.3)\end{array}$ & 30 \\
\hline CPR/AED and First Aid training required for head coaches & $\begin{array}{c}2 \\
(100)\end{array}$ & $\begin{array}{c}0 \\
(0 \%)\end{array}$ & $\begin{array}{c}0 \\
(0 \%)\end{array}$ & 2 \\
\hline $\begin{array}{l}\text { Require 4th Edition PPE forms from American Academy of Pediatrics of } \\
\text { equivalent - Sickle Cell Trait }\end{array}$ & $\begin{array}{c}29 \\
(100)\end{array}$ & $\begin{array}{c}0 \\
(0 \%)\end{array}$ & $\begin{array}{c}0 \\
(0 \%)\end{array}$ & 29 \\
\hline $\begin{array}{l}\text { Conditioning periods should be phased in gradually and progressively to } \\
\text { minimize risk of injury during transitional periods. Also, Introduce new } \\
\text { conditioning activities gradually, especially during the early stages of a } \\
\text { conditioning program }\end{array}$ & $\begin{array}{c}2 \\
(100)\end{array}$ & $\begin{array}{c}0 \\
(0 \%)\end{array}$ & $\begin{array}{c}0 \\
(0 \%)\end{array}$ & 2 \\
\hline $\begin{array}{l}\text { Exercise and conditioning activities are not permitted to be used as } \\
\text { punishment }\end{array}$ & $\begin{array}{c}0 \\
(0 \%)\end{array}$ & $\begin{array}{c}0 \\
(0 \%)\end{array}$ & $\begin{array}{c}0 \\
(0 \%)\end{array}$ & 0 \\
\hline $\begin{array}{l}\text { Requires appropriate supervision (i.e., coach certified in CPR/First Aid with } \\
\text { education on the prevention of sudden death in sport or an Athletic Trainer } \\
\text { onsite) }\end{array}$ & $\begin{array}{c}1 \\
(100)\end{array}$ & $\begin{array}{c}0 \\
(0 \%)\end{array}$ & $\begin{array}{c}0 \\
(0 \%)\end{array}$ & 1 \\
\hline
\end{tabular}

\section{Categorical Analysis}

Overall, the prevalence of policies required by the SHSAA was higher in the EHS section compared to all other categories combined (EHS $=99.35 \%$ versus all other categories combined $=45.81 \% ; \mathrm{PR}=2.17 ; 95 \% \mathrm{Cl}=2.00,2.35$ ) (Table 5). A majority of policies required by LEGIS were found in the SCA section compared to all other categories combined (SCA $=79.70 \%$ vs all others $=11.23 \%$; $\mathrm{PR}=7.09 ; 95 \% \mathrm{Cl}=5.73,8.79$ ). The category that most frequently found policies in $\mathrm{BOTH}$ was $\mathrm{THI}(\mathrm{THI}=29.16 \%$, all others $=2.25 \%$; $\mathrm{PR}=12.96 ; 95 \% \mathrm{Cl}=7.81,21.53)$.

Table 5. Categorical analysis by emergency related category and governing body. Values presented as $n(\%)$.

\begin{tabular}{|c|c|c|c|c|}
\hline & SCA & EHS & THI & EP \\
\hline SHSAA & $\begin{array}{c}44 \\
(16.23)\end{array}$ & $\begin{array}{c}309 \\
(99.35)^{*}\end{array}$ & $\begin{array}{c}87 \\
(45.31)\end{array}$ & $\begin{array}{c}181 \\
(83.02)\end{array}$ \\
\hline LEGIS & $\begin{array}{c}216 \\
(79.70)^{*}\end{array}$ & $\begin{array}{c}1 \\
(3.21)\end{array}$ & $\begin{array}{c}49 \\
(25.52)\end{array}$ & $\begin{array}{c}31 \\
(14.22)\end{array}$ \\
\hline BOTH & $\begin{array}{c}11 \\
(4.05)\end{array}$ & $\begin{array}{c}1 \\
(3.21)\end{array}$ & $\begin{array}{c}56 \\
(29.16)^{\wedge}\end{array}$ & $\begin{array}{c}6 \\
(2.75)\end{array}$ \\
\hline Total policies required & 271 & 311 & 192 & 218 \\
\hline
\end{tabular}

Abbreviations: exertional heat stroke (EHS), traumatic head injuries (THI), sudden cardiac arrest (SCA), and emergency preparedness (EP)

${ }^{*}$ significantly higher than all other categories combined

${ }^{\wedge}$ most frequent policy in BOTH

\section{DISCUSSION}

The purpose of this study was to describe where secondary school health and safety policies were located at the state level for four emergency related categories. We found that the location of different policies within each state varied by category. In general, EHS and EP policies were most often found within SHSAA, whereas THI and SCA were most commonly found in LEGIS. Interestingly, we did not find that any policy category was most often found in BOTH, yet THI did have the greatest variability across 
governing entities. Through the identification of where these health and safety policies were located, we can better support and guide states to identify the best avenue for them to pursue the implementation of health and safety standards.

The majority of policies on EHS and EP are found in SHSAA (EHS=99.35\%, EP = 83.02\%). It is possible that because both of these policies are sport-specific (e.g., EHS typically occurs in athletes, EP includes the development of athletics-specific emergency action plans), that this is a contributing factor for why these policies are most often required by SHSAAs. ${ }^{14,17}$ Also, EHS rates are considered low when compared to sports-related orthopedic injuries. ${ }^{18}$ Yet, when EHS is not treated correctly, cases are fatal. ${ }^{17,19,20}$ Even though each state's athletes experience a variety of exertional heat illnesses that can be reduced by EHS policies, not every state experiences an EHS or is unaware one occurred unless it was fatal. ${ }^{19}$ Without a feeling of personal connection, LEGIS may not see a need to progress EHS policy forward. Specifically, the use of health behavior theories and models such as the Health Belief Model, Transtheoretical Model of Change or the Precaution Adoption Process Model, can aid in the understanding of someone's readiness to act for the adoption of these policies. ${ }^{21-24}$ Emergency preparedness policies are needed for sportspecific venues so as to ensure a fast response from EMS when called onsite to manage a potential catastrophic injury. ${ }^{25-27}$ However, LEGIS may assume because emergency policies are required for secondary schools (i.e. fire, disaster), that sportspecific polices are already included, or not needed.

In this investigation, we identify that a majority (79.7\%) of SCA policies emanate from LEGIS. Sudden cardiac arrest, the leading cause of death in sport and physical activity, is a threat across the life span, ${ }^{28}$ not just secondary school student-athletes. Individuals with a family history of heart problems, people who are considered geriatric, bariatric, smokers, high school and youth athletes are all considered at risk for SCA. ${ }^{28}$ Thus, given the potential for a wide range of populations to be affected by a potential SCA, it may be possible that LEGIS bodies identified the risk and aimed to implement these policies to protect a wide variety of constituents. An increase in perceived risk can lead to a greater degree of perceived necessity for SCA policies. As public awareness of an issue like SCA increases, states may feel an increased pressure to address the issue; this is known as normative isomorphism. ${ }^{29}$ During normative isomorphism, an organization makes changes to adhere to social or environmental norms and expectations. ${ }^{29}$

Though THI appear to be most frequently located in SHSAA's, this was the only category with a larger distribution across SHSAA, LEGIS and BOTH. Traumatic head injuries have become a growing concern in recent years, and research on THI has dramatically increased. ${ }^{22}$ In 2008, 1372 peer reviewed articles were published on the subject of THI and indexed in PubMed (search term: traumatic head injury), and no states had THI laws in place. 30,31 In 2018, 2,970 peer reviewed articles were published and indexed in PubMed, and every state had a law regarding THI. ${ }^{30,31}$ Increased awareness and education at the community level of the socioecological framework may have spurred these actions at the policy level by both SHSAA and LEGIS. ${ }^{8}$ Some bodies may have felt the need to implement health and safety policies due to mimetic isomorphism, which is defined as a theory of change in which an organization makes changes in order to maintain similarity to other organizations. ${ }^{12,29}$ The presence of THI policies within both bodies may also be the result of coercive isomorphism, in which an entity changes to meet a professional standard. ${ }^{29}$ If one entity passes a policy requiring certain standards for care and precautions surrounding $\mathrm{TH}$, the other entity may be forced to pass similar policies in order to adhere to standards.

Health and safety policies implemented by SHSAA's may have greater awareness of how best to encourage change among their member schools. When compared to state legislative bodies, SHSAA's ratify policy through a simpler process by involving fewer members and thus may have greater flexibility regarding the way in which policies are ratified. SHSAA's also have a direct impact on the implementation of those policies as they communicate policy updates annually with their schools. However, unlike the NCAA that can deploy financial fines or post season restrictions for non-compliance, SHSAA's often do not have the same consequences. ${ }^{32}$ LEGIS can influence not just public secondary schools, but private schools as well. The potential for criminal charges associated with violating legislative, particularly in sport related catastrophic injuries, may encourage policy compliance. When attempting to progress a policy through LEGIS, legislative study resolutions or costs analyses often present as a typical legislative resistance which can explain why fewer policies are located in LEGIS. The coordination of both bodies' aids in the education for stakeholders on specific issues. Education may be able to facilitate change more efficiently and effectively and, therefore, further preventing sudden death in sport. Comprehensive policies could potentially enforce standards of care and safety, while creating a societal trend of education and awareness surrounding strategies which prevent catastrophic injury. Provided the purpose of this investigation was to simply describe the location of these policies, our study did not aim to evaluate which governing entity was better at implementing policy. However, by evaluating injury epidemiology rates across the nation in context of our results, we believe future research may be able to ascertain if SHSAA, LEGIS or BOTH result in improved policy implementation at the local level. 


\section{CONCLUSIONS}

Observing the specific location of each policy allows for a better understanding of the governing bodies that are typically requiring secondary school health and safety policies across the nation. By understanding the governing body most frequently requiring a certain policy, future advocacy efforts can target specific governing bodies. For example, a majority of EP and EHS policies were required by the SHSAA, indicating it may be easier to implement these policies at the SHSAA rather than LEGIS. Conversely, if a state is lacking a THI policy, these data show a more variable distribution between SHSAA, LEGIS and BOTH. Therefore, advocacy efforts may be warranted towards both SHSAA and LEGIS to collaborate on a unified policy. Overall, this study provides foundational data as to where health and safety policies for EHS, THI, SCA and EP are located. These data can aid in the guidance of key stakeholders in states aiming to move forward with new requirements in the future. Specifically, these findings can provide a starting point for states to consider when requiring a new policy.

\section{REFERENCES}

1. Casa DJ, Almquist J, Anderson SA, et al. The inter-association task force for preventing sudden death in secondary school athletics programs: best-practices recommendations. Journal of Athletic Training. 2013;48(4):546-553.

2. Casa DJ, Guskiewicz KM, Anderson SA, et al. National athletic trainers' association position statement: preventing sudden death in sports. Journal of Athletic Training. 2012;47(1):96-118.

3. Boden BP, Breit I, Beachler JA, Williams A, Mueller FO. Fatalities in High School and College Football Players. The American Journal of Sports Medicine. 2013;41(5):1108-1116.

4. Kerr ZY, Register-Mihalik JK, Pryor RR, et al. The Association between Mandated Preseason Heat Acclimatization Guidelines and Exertional Heat Illness during Preseason High School American Football Practices. Environmental Health Perspectives. 2019;127(4):047003. doi:10.1289/EHP4163

5. Emery CA. Risk factors for injury in child and adolescent sport: a systematic review of the literature. Clinical Journal of Sport Medicine. 2003 Jul;13(4):256-268.

6. $\quad$ Bronfenbrenner U. The Ecology of Human Development. Berlin, Heidelberg; 2009.

7. McLeroy KR, Bibeau D, Steckler A. An ecological perspective on health promotion programs. Health Educ. Q. 1988;15(4):351-377.

8. Scarneo S, Kerr ZY, Kroshus E, et al. The Socio-Ecological Framework: A Multi-Faceted Approach to Prevent SportRelated Death in High School Sports. Journal of Athletic Training. 2019;54(4):356-360. doi:10.4085/1062-6050-173-18

9. Adams WM, Scarneo SE, Casa DJ. State-Level Implementation of Health and Safety Policies to Prevent Sudden Death and Catastrophic Injuries Within Secondary School Athletics. Orthopaedic Journal of Sports Medicine. 2017;5(9):1-8.

10. Scarneo-Miller SE, DiStefano LJ, Singe SM, Register-Mihalik JK, Stearns RL, Casa DJ. Emergency Action Plans in Secondary Schools: Barriers, Facilitators, and Social Determinants Affecting Implementation. Journal of Athletic Training. 2020;55(1):80-87. doi:10.4085/1062-6050-484-18

11. Johnson S, Norcross MF, Bovbjerg V, Koester M. Barriers and Facilitators of Implementing Emergency Action Plans in Oregon High Schools. Journal of Athletic Training. 2018;53(6(S)):S-216.

12. Pagnotta KD, Mazerolle SM, Pitney WA, Burton LJ, Casa DJ. Implementing Health and Safety Policy Changes at the High School Level From a Leadership Perspective. Journal of Athletic Training. 2016;51(4):291-302.

13. Broglio SP, Cantu RC, Gioia GA, et al. National Athletic Trainers' Association position statement: management of sport concussion. Journal of Athletic Training. 2014;49(2):245-265.

14. Andersen J, Courson RW, Kleiner DM, McLoda TA. National Athletic Trainers' Association Position Statement: Emergency Planning in Athletics. Journal of Athletic Training. 2002;37(1):99-104.

15. Drezner JA, Courson RW, Roberts WO, et al. Inter Association Task Force recommendations on emergency preparedness and management of sudden cardiac arrest in high school and college athletic programs: a consensus statement. Prehosp Emerg Care. Jul-Sep 2007;11(3):253-271.

16. McCrory P, Meeuwisse WH, Aubry M, et al. Consensus Statement on Concussion in Sport: The 4th International Conference on Concussion in Sport, Zurich, November 2012. dx.doi.org. 2013;48(4):554-575.

17. Casa DJ, DeMartini JK, Bergeron MF, et al. National Athletic Trainers' Association Position Statement: Exertional Heat Illnesses. Journal of Athletic Training. 2015;50(9):986-1000.

18. Kerr ZY, Casa DJ, Marshall SW, Comstock RD. Epidemiology of Exertional Heat Illness Among U.S. High School Athletes. American Journal of Preventive Medicine. 2013;44(1):8-14. doi:10.1016/j.amepre.2012.09.058

19. Grundstein AJ, Hosokawa Y, Casa DJ. Fatal Exertional Heat Stroke and American Football Players: The Need for Regional Heat-Safety Guidelines. Journal of Athletic Training. 2018;53(1):43-50.

20. Demartini JK, Casa DJ, Stearns R, et al. Effectiveness of cold water immersion in the treatment of exertional heat stroke at the Falmouth Road Race. Medicine \& Science in Sports \& Exercise. 2015;47(2):240-245.

21. Sallis JF, Owen N, Fisher EB. Ecological models of health behavior. Health Behavior and Vdots. 2008;(2). 
22. Weinstein ND, Sandman PM, Blalock SJ. The Precaution Adoption Process Model. In: Health Behavior and Health Education. Vol 21. 4th ed. San Fancisco: Jossey-Bass; 2008:123-147.

23. Kersell MW, Milsum JH. A systems model of health behavior change. Behavioral Science. 1985;30(3):119-126.

24. Glanz K, Rimer B, Viswanath KV, eds. Health Behavior: Theory, Research and Practice. 5th ed. Jossey-Bass; 2015.

25. Blackwell TH, Kaufman JS. Response time effectiveness: comparison of response time and survival in an urban emergency medical services system. Acad Emerg Med. 2002;9(4):288-295.

26. Barishansky RM, O'Connor KE. Best practices in emergency medical services. Clinical response planning-syndromic surveillance. Emergency Medical Services. 2005;34(3):84-86.

27. Drezner JA, Rao AL, Heistand J, Bloomingdale MK, Harmon KG. Effectiveness of emergency response planning for sudden cardiac arrest in United States high schools with automated external defibrillators. Circulation. 2009;120(6):518525 .

28. Casa DJ, Stearns RL. Preventing Sudden Death in Sport \& Physical Activity. 2nd ed. Jones \& Bartlett Learning; 2017.

29. DiMaggio PJ, Powell WW. The Iron Cage Revisited: Institutional Isomorphism and Collective Rationality in Organizational Fields. American Sociological Review. 1983;48(2):147. doi:10.2307/2095101

30. PubMed Index of "Traumatic Head Injury" Manuscripts. https://www-ncbi-nlm-nihgov.ezproxy.lib.uconn.edu/pubmed/?term=traumatic+head+injury. Accessed April 15, 2020.

31. LaRoche AA, Nelson LD, Connelly PK, Walter KD, McCrea MA. Sport-Related Concussion Reporting and State Legislative Effects: Clinical Journal of Sport Medicine. 2016;26(1):33-39. doi:10.1097/JSM.0000000000000192

32. NCAA 2019-20 Division 1 Manual.; 2019. https://web3.ncaa.org//sdbi/reports/getReport/90008. Accessed April 15, 2020. 